\title{
Awareness of Oral Hygiene among Dental College Students in Namakkal, Tamil Nadu, India: A Cross-sectional Analysis
}

\author{
Nazargi Mahabob ${ }^{1}$, Senthil Kumar², Surya Thangam ${ }^{3}$
}

\begin{abstract}
Aim and objective: To assess the influence of educational level and gender on oral hygiene knowledge, attitude, and behavior among undergraduate dental students.

Materials and methods: A cross-sectional study was carried out, including 357 students and interns of a dental college in Namakkal, Tamil Nadu, India. A self-administered anonymous and close-ended questionnaire based on the Hiroshima University-Dental Behavior Inventory was designed and administered voluntarily to students and interns in October 2019 to survey their oral hygiene knowledge and attitude. The questionnaire consisted of 20 questions. The study group consisted of 1st-year students (98), 2nd-year students (91), 3rd-year students (62), 4 th-year students (47), and 59 interns. Collected data were coded and analyzed using SPSS version 21.0. Participants' responses were assessed according to their educational level and gender using the Chi-square test, and the significance level was set at $p \leq 0.05$.

Results: In this study, the response rate was $100 \%$. Responses to some of the questions showed significant variability. The oral health behavior of participants varies not only with their gender but also with their educational level, i.e., the amount of clinical exposure and experience.

Conclusion: We conclude that knowledge and information play a crucial role in modifying one's psychology, despite gender-based variation in behavior. Therefore, we recommend that the government includes chapters on some basic knowledge related to oral health in the school syllabus, such as basic science subjects, or a compulsory dental awareness program in the school curriculum.

Keywords: Awareness, Dental education, Gender, Oral hygiene.

Journal of Health Sciences \& Research (2020): 10.5005/jp-journals-10042-1096
\end{abstract}

\section{INTRODUCTION}

Maintaining good oral hygiene is important for overall health and well-being. The attitude toward oral health determines the quality of oral health. ${ }^{1,2}$ Habits become attitudes, and attitudes determine the behavior of a person. Attitude is an acquired characteristic that reflects an individual's cultural, familial, and life experiences, and strongly influences an individual's behavior. Similarly, oral hygiene depends on the attitude toward oral health. The dissemination of hygiene practices is achieved through different sources, such as mass media, parents, friends, and healthcare professionals and paraprofessionals. ${ }^{3}$ Healthcare professionals play an important role in guiding their patients through hygiene practices. Even though people are from different cultures and socioeconomic backgrounds, they expect their oral health providers to have good oral hygiene. If oral health providers do not pay attention to their own oral health, it could affect their ability to deliver oral health care to their patients. ${ }^{4}$ Thus, they should become role models for the community in maintaining good oral health. ${ }^{5}$ Dentists acquire their oral health knowledge at the time of studying dentistry. Evidence suggests that the oral hygiene knowledge and behavior of dental students vary in clinical and preclinical years of dental education because of the clinical experience that shapes their attitude toward oral hygiene. ${ }^{6}$ The inclusion of syllabus related to oral care in the preuniversity curriculum may influence the oral health behavior of students entering dentistry. A previous study reported that children with adequate knowledge toward oral health maintenance were less likely to develop dental caries than those without sufficient oral health knowledge. ${ }^{7}$

The aim of this study is to evaluate (1) the oral hygiene knowledge and attitude of clinical and preclinical students in our
${ }^{1}$ Department of Oral and Maxillofacial Surgery and Diagnostic Sciences, King Faisal University, Al Hasa, Eastern Province, Saudi Arabia ${ }^{2}$ Department of Oral Medicine, KSR Institute of Dental Science and Research, Namakkal, Tamil Nadu, India

${ }^{3}$ Department of Oral Medicine and Radiology, KSR Institute of Dental Science and Research, Attur, Tamil Nadu, India

Corresponding Author: Nazargi Mahabob, Department of Oral and Maxillofacial Surgery and Diagnostic Sciences, King Faisal University, Al Hasa, Eastern Province, Saudi Arabia, Phone: +966 0559118827, e-mail: nazargimahabob@yahoo.com

How to cite this article: Mahabob N, Kumar S, Thangam S. Awareness of Oral Hygiene among Dental College Students in Namakkal, Tamil Nadu, India: A Cross-sectional Analysis. J Health Sci Res 2020;11(2):53-57.

Source of support: Nil

Conflict of interest: None

college and (2) gender-based variations in oral hygiene knowledge and attitude of those students.

\section{Materials and Methods Study Setting and Design}

A cross-sectional study was carried out among students and interns of a dental college in Namakkal, Tamil Nadu, India. A self-administered and close-ended questionnaire based on the Hiroshima University-Dental Behavioral Inventory (HU-DBI) was designed and distributed among the undergraduate dental students and interns in October 2019. The research has been 
conducted in accordance with the World Medical Association Declaration of Helsinki. The questionnaire consisted of 20 questions and asked for consent to participate in this study; the study was conducted only after obtaining consent from the participants. Confidentiality and anonymity were confirmed so that responses could not be linked to individual participants.

\section{Sampling Criteria}

To assess the oral hygiene attitude and behavior of the students in our dental college, all undergraduate dental students in their 1st, 2nd, 3rd, 4th, and 5th year of dental college were included in this study. Absentees and incomplete forms were excluded. Totally, 357 dental students and interns were surveyed using the English version of a self-administered $\mathrm{HU}-\mathrm{DBI}$ questionnaire, originally developed by Kawamura et al. ${ }^{8}$ The study group consisted of 98 1st-year students, 91 2nd-year students, 62 3rd-year students, 47 4th -year students, and 59 interns. One score was given for each "agree" response to items 4, 9, 11, 12, 16, and 19, and one score was given for each "disagree" response to items 2, 6, 8, 10, 14, and 15. The maximum possible score was 12 , and the minimum possible score was 0 . The higher the score, the better the oral health attitude and behavior.

\section{Survey Method}

All students and interns were asked to stay in their classes after their lecture hour, and the questionnaire was distributed among them. Of 371 students and interns, 357 were present at the time of the survey. Attempts were not made to follow up those $(n=14)$ who were absent at the time of the survey, and they were excluded. All students and interns were informed about this voluntary study prior to the survey. The purpose of this study was explained to them, and their doubts were cleared. Participants completed the questionnaire anonymously, and no personal data were collected other than their age, year of study, and gender. Of 357 participants, 59 were interns, 109 were clinical students, and 189 were preclinical students.

\section{Statistical Analysis}

Collected data were coded and analyzed using SPSS version 21.0 (IBM Corp., Armonk, NY, United States). The differences in response were analyzed based on the participants' age and year of study using the Chi-square test, and the significance level was set at $p \leq 0.05$. Descriptive statistics, calculated in terms of percentages and frequencies were used to describe the data.

\section{Results}

Of 371 undergraduate dental students and interns, 357 took part in the study, and 14 were absent; the response rate was 100\%. Table 1 shows the categorization of participants according to their age and year of study. Approximately $53 \%$ of the participants were from preclinical years; there were 70 (19.6\%) male and 287 (80.4\%) female participants. Participants were within the age range of 18 to 24 years with a mean age of 20.38 years (Table 1). Participants were categorized based on their years of study and gender (Table 2).

The mean HU-DBI score of clinical students was significantly higher than that of preclinical students $(p<0.05)$. Similarly, the mean score differed significantly between genders (Table 2).

Table 3 shows participants' responses to all 20 questions, according to their level of dental education. In comparison with clinical students (41.9 vs $73 \%$ ), preclinical students worried less about visiting their dentist. Consequently, a higher number of preclinical students delayed their dental visits until they experienced
Table 1: Distribution of students according to age and year of study

\begin{tabular}{lclc}
\hline $\begin{array}{l}\text { Year of study } \\
\text { (BDS) }\end{array}$ & $\begin{array}{l}\text { Number of } \\
\text { students (\%) }\end{array}$ & Response rate (\%) & $\begin{array}{l}\text { Mean age } \\
\text { (years) }\end{array}$ \\
\hline First year & $98(27.5)$ & 100 & 18.4 \\
Second year & $91(25.5)$ & 100 & 19.3 \\
Third year & $62(17.4)$ & 100 & 20.2 \\
Fourth year & $47(13.2)$ & 100 & 21.3 \\
Interns & $59(16.5)$ & 100 & 22.7 \\
Total & $357(100)$ & 100 & 20.38 \\
\hline
\end{tabular}

Table 2: Mean scores of HU-DBI questionnaire among preclinical and clinical students

\begin{tabular}{lrcl}
\hline Year & $N(\%)$ & Mean scores $\pm S D$ & $p$ \\
\hline Preclinical & $189(52.9)$ & $7.6 \pm 2.10$ & 0.023 \\
Clinical & $168(47.1)$ & $8.02 \pm 2.16$ & 0.036 \\
Male & $70(19.6)$ & $7.2 \pm 2.21$ & 0.043 \\
Female & $287(80.4)$ & $8.6 \pm 2.24$ & 0.031 \\
\hline
\end{tabular}

$p$ value fixed at $\leq 0.05 ; \mathrm{SD}$, standard deviation; HU-DBI, Hiroshima UniversityDental Behavioral Inventory

toothache than clinical students (56.1 vs 37.5\%). Preclinical students (41.8\%) frequently noticed white-colored sticky deposits on their teeth than clinical students (31\%). However, a higher number of clinical students were concerned about having halitosis (82.7 vs $69.8 \%$ ) and brushed their teeth regularly and carefully (93.5 vs $65.6 \%$ ) than preclinical students. Concerning the size of toothbrush used by the participants, more preclinical students accepted that they were using child-size toothbrush than clinical students (13.8 vs $1.8 \%$ ). Regarding the question related to the tendency of having bleeding gums, only $7.7 \%$ of clinical students noticed gingival bleeding in comparison with $40.7 \%$ of preclinical students.

Most of the clinical (85.7\%) and preclinical (76.7\%) students did not use hard-bristled toothbrushes, and $94 \%$ of clinical students responded that they had the habit of checking their teeth after brushing compared with $41.3 \%$ of preclinical students.

Table 4 shows differences in responses according to the gender of the participants. A higher number of male participants did not worry about consulting a dental surgeon than female participants (52.9 vs $34.1 \%$ ), and more male participants delayed their dental checkups until they experienced a problem than female participants (62.9 vs $40.4 \%)$. However, $45.7 \%$ of male participants noticed white deposits on their teeth surfaces than $32.8 \%$ of female participants, and a higher number of female participants were bothered about halitosis than male participants ( 82.2 vs $72.9 \%$ ). There was no significant difference in the number of female and male participants who were using child-size toothbrush ( 9.8 vs $11.4 \%, p=0.027$ ). Female participants less frequently noticed that their gingiva had a tendency to bleed after brushing than male participants (33.4 vs $34.3 \%)$, although more females agreed that they had the habit of checking their teeth after brushing than male participants (86.4 vs $61.4 \%)$.

\section{Discussion}

To prevent oral diseases, oral health providers must educate their patients about the importance of proper oral habits, which they can achieve by becoming a role model for their patients. ${ }^{7}$ Proper oral 
Table 3: Dental students' responses (preclinical and clinical) to HU-DBI questionnaire

\begin{tabular}{|c|c|c|c|c|c|}
\hline $\begin{array}{l}\text { Sl. } \\
\text { No. }\end{array}$ & Question & & $\begin{array}{l}\text { Preclinical } \\
n(\%)\end{array}$ & $\begin{array}{l}\text { Clinical } \\
n(\%)\end{array}$ & $p$ value \\
\hline \multirow[t]{2}{*}{1} & \multirow{2}{*}{$\begin{array}{l}\text { I do not worry } \\
\text { much about } \\
\text { visiting the } \\
\text { dentist }\end{array}$} & Agree & $138(73)$ & $82(41.9)$ & 0.223 \\
\hline & & Disagree & $51(27)$ & $86(51.1)$ & \\
\hline \multirow[t]{2}{*}{2} & \multirow{2}{*}{$\begin{array}{l}\text { My gums tend } \\
\text { to bleed when I } \\
\text { brush my teeth }\end{array}$} & Agree & 77 (40.7) & $13(7.7)$ & 0.001 \\
\hline & & Disagree & $112(59.3)$ & $155(92.3)$ & \\
\hline \multirow[t]{2}{*}{3} & \multirow{2}{*}{$\begin{array}{l}\text { I worry about } \\
\text { the color of my } \\
\text { teeth }\end{array}$} & Agree & $134(70.9)$ & $149(88.7)$ & 0.042 \\
\hline & & Disagree & $55(29.1)$ & $19(11.3)$ & \\
\hline \multirow[t]{2}{*}{4} & \multirow{2}{*}{$\begin{array}{l}\text { I have noticed } \\
\text { white sticky } \\
\text { deposits on my } \\
\text { teeth }\end{array}$} & Agree & 79 (41.8) & $52(31)$ & 0.021 \\
\hline & & Disagree & $110(58.2)$ & $116(69)$ & \\
\hline \multirow[t]{2}{*}{5} & \multirow{2}{*}{$\begin{array}{l}\text { I use a child-size } \\
\text { toothbrush }\end{array}$} & Agree & $26(13.8)$ & $3(1.8)$ & 0.069 \\
\hline & & Disagree & $163(86.2)$ & $165(98.2)$ & \\
\hline \multirow[t]{2}{*}{6} & \multirow{2}{*}{$\begin{array}{l}\text { I think that I } \\
\text { cannot help } \\
\text { having false } \\
\text { teeth when I am } \\
\text { old }\end{array}$} & Agree & $62(32.8)$ & $63(37.5)$ & 0.021 \\
\hline & & Disagree & $127(67.2)$ & $105(62.5)$ & \\
\hline \multirow[t]{2}{*}{7} & \multirow{2}{*}{$\begin{array}{l}\text { I am bothered by } \\
\text { the color of my } \\
\text { gums }\end{array}$} & Agree & $67(35.4)$ & $34(20.2)$ & 0.346 \\
\hline & & Disagree & $122(64.6)$ & $134(79.8)$ & \\
\hline \multirow[t]{2}{*}{8} & \multirow{2}{*}{$\begin{array}{l}\text { I think my teeth } \\
\text { are getting } \\
\text { worse despite } \\
\text { my daily } \\
\text { brushings }\end{array}$} & Agree & $77(40.7)$ & $22(13.1)$ & 0.001 \\
\hline & & Disagree & $112(59.3)$ & $146(86.9)$ & \\
\hline \multirow[t]{2}{*}{9} & \multirow{2}{*}{$\begin{array}{l}\text { I brush each } \\
\text { of my teeth } \\
\text { carefully }\end{array}$} & Agree & $124(65.6)$ & $157(93.5)$ & 0.017 \\
\hline & & Disagree & 65 (34.4) & $11(6.5)$ & \\
\hline \multirow[t]{2}{*}{10} & \multirow{2}{*}{$\begin{array}{l}\text { I have never } \\
\text { been taught } \\
\text { professionally } \\
\text { how to brush }\end{array}$} & Agree & $76(41.2)$ & $36(21.4)$ & 0.002 \\
\hline & & Disagree & $113(59.8)$ & $132(78.6)$ & \\
\hline \multirow[t]{2}{*}{11} & \multirow{2}{*}{$\begin{array}{l}\text { I think I can clean } \\
\text { my teeth well } \\
\text { without using a } \\
\text { toothbrush }\end{array}$} & Agree & 34 (18) & 19 (11.3) & 0.005 \\
\hline & & Disagree & $155(82)$ & $149(88.7)$ & \\
\hline \multirow[t]{2}{*}{12} & \multirow{2}{*}{$\begin{array}{l}\text { I often check } \\
\text { my teeth in the } \\
\text { mirror after } \\
\text { brushing }\end{array}$} & Agree & $78(41.3)$ & 158 (94) & 0.001 \\
\hline & & Disagree & $111(58.7)$ & $10(6)$ & \\
\hline \multirow[t]{2}{*}{13} & \multirow{2}{*}{$\begin{array}{l}\text { I worry about } \\
\text { having bad } \\
\text { breath }\end{array}$} & Agree & $132(69.8)$ & $138(82.7)$ & 0.012 \\
\hline & & Disagree & $57(30.2)$ & $29(17.3)$ & \\
\hline \multirow[t]{2}{*}{14} & \multirow{2}{*}{$\begin{array}{l}\text { It is impossible } \\
\text { to prevent gum } \\
\text { diseases with } \\
\text { toothbrushing } \\
\text { alone }\end{array}$} & Agree & $103(54.5)$ & 109 (64.9) & 0.179 \\
\hline & & Disagree & $86(45.5)$ & $59(35.1)$ & \\
\hline \multirow[t]{2}{*}{15} & \multirow{2}{*}{$\begin{array}{l}\text { I put off going } \\
\text { to the dentist } \\
\text { until I have a } \\
\text { toothache }\end{array}$} & Agree & $106(56.1)$ & $63(37.5)$ & 0.006 \\
\hline & & Disagree & $83(43.9)$ & $105(62.5)$ & \\
\hline
\end{tabular}

\begin{tabular}{|c|c|c|c|c|c|}
\hline $\begin{array}{l}\text { SI. } \\
\text { No. }\end{array}$ & Question & & $\begin{array}{l}\text { Preclinical } \\
n()\end{array}$ & $\begin{array}{l}\text { Clinical } \\
n()\end{array}$ & $p$ value \\
\hline \multirow[t]{2}{*}{16} & \multirow{2}{*}{$\begin{array}{l}\text { I have used a dye } \\
\text { to see how clean } \\
\text { my teeth are }\end{array}$} & Agree & $58(30.7)$ & 29 (17.3) & \multirow[t]{2}{*}{0.027} \\
\hline & & Disagree & $131(69.3)$ & $130(82.7)$ & \\
\hline \multirow[t]{2}{*}{17} & \multirow{2}{*}{$\begin{array}{l}\text { I use a } \\
\text { toothbrush } \\
\text { which has hard } \\
\text { bristles }\end{array}$} & Agree & $44(23.3)$ & 24 (14.3) & \multirow[t]{2}{*}{0.001} \\
\hline & & Disagree & $145(76.7)$ & $144(85.7)$ & \\
\hline \multirow[t]{2}{*}{18} & \multirow{2}{*}{$\begin{array}{l}\text { I do not feel I } \\
\text { have brushed } \\
\text { well unless } \\
\text { I brush with } \\
\text { strong strokes }\end{array}$} & Agree & $76(40.2)$ & 29 (17.3) & \multirow[t]{2}{*}{0.227} \\
\hline & & Disagree & $113(59.8)$ & $139(82.7)$ & \\
\hline \multirow[t]{2}{*}{19} & \multirow{2}{*}{$\begin{array}{l}\text { I feel I } \\
\text { sometimes take } \\
\text { too much time to } \\
\text { brush my teeth }\end{array}$} & Agree & 78 (41.3) & $77(45.8)$ & \multirow[t]{2}{*}{0.002} \\
\hline & & Disagree & $111(58.1)$ & $97(54.2)$ & \\
\hline \multirow[t]{2}{*}{20} & \multirow{2}{*}{$\begin{array}{l}\text { I have had my } \\
\text { dentist tell me } \\
\text { that I brush very } \\
\text { well }\end{array}$} & Agree & $121(64)$ & $71(42.3)$ & \multirow[t]{2}{*}{0.017} \\
\hline & & Disagree & $68(36)$ & $97(57.7)$ & \\
\hline
\end{tabular}

habits in patients can be achieved by providing them with relevant information and proper education. ${ }^{8,9}$

Since dentists play a central role in the provision of oral health care, they are considered experts in the area of oral health awareness and promotion. As future dentists, dental students should have proper knowledge about oral hygiene that enables them to evaluate, educate, and motivate their patients. ${ }^{10,11}$ There is only a limited awareness of dental health among the common population, as well as no emphasis on dental health awareness in the school curriculum. Therefore, common people depend on mass media to know about dental health care, which is sometimes wrong or exaggerated from a business point of view. ${ }^{12}$ According to Swathi et al., oral hygiene awareness among dental students increases with their level of education. ${ }^{13}$ In our study, the mean HU-DBI score showed that students in the clinical years had better oral health attitudes than those who did not attend their clinical posting, indicating that students' level of education and amount of clinical exposure modify their level of oral health knowledge. In our study, fewer preclinical students showed interest in visiting a dental surgeon in comparison with clinical students, similar to the results of a study by Alam Moheet et al. ${ }^{14}$ In this study, we found that a higher number of preclinical students agreed that they noticed gingival bleeding after brushing than clinical students. Since clinical students were taught about and trained on brushing techniques, they had better knowledge than preclinical students, similar to the outcomes of previous studies. ${ }^{11,15}$ Saran et al. reported that preclinical students delayed their visit to a dentist till they experience a toothache, in comparison with clinical students. ${ }^{16}$ However, in our study, clinical students agreed that they frequently consulted dentists.

Similar to previous studies by Zetu et al. ${ }^{17}$ and Ozyemisci-Cebeci et al., ${ }^{18}$ this study showed that a higher number of preclinical students had the habit of vigorous brushing and noticed that the condition of their teeth did not improve even after regular brushing. These findings indicate improper toothbrushing habits and the absence of adequate oral health knowledge among preclinical students. 
Table 4: Dental students' responses (gender based) to HU-DBI questionnaire

\begin{tabular}{|c|c|c|c|c|c|}
\hline Sl. No. & Question & & $\begin{array}{l}\text { Male } \\
n(\%)\end{array}$ & $\begin{array}{l}\text { Female } \\
n(\%)\end{array}$ & $p$ value \\
\hline \multirow[t]{2}{*}{1} & \multirow[t]{2}{*}{ I do not worry much about visiting the dentist } & Agree & $37(52.9)$ & $98(34.1)$ & \multirow{2}{*}{0.023} \\
\hline & & Disagree & $33(47.1)$ & $189(65.9)$ & \\
\hline \multirow[t]{2}{*}{2} & \multirow[t]{2}{*}{ My gums tend to bleed when I brush my teeth } & Agree & $24(34.3)$ & $96(33.4)$ & \multirow{2}{*}{0.052} \\
\hline & & Disagree & $46(65.1)$ & $191(66.6)$ & \\
\hline \multirow[t]{2}{*}{3} & \multirow[t]{2}{*}{ I worry about the color of my teeth } & Agree & $56(81.4)$ & $242(84.2)$ & \multirow{2}{*}{0.038} \\
\hline & & Disagree & $14(18.6)$ & 45 (15.7) & \\
\hline \multirow[t]{2}{*}{4} & \multirow[t]{2}{*}{ I have noticed white sticky deposits on my teeth } & Agree & $32(45.7)$ & $94(32.8)$ & \multirow{2}{*}{0.046} \\
\hline & & Disagree & $38(54.3)$ & $193(67.2)$ & \\
\hline \multirow[t]{2}{*}{5} & \multirow[t]{2}{*}{ I use a child-size toothbrush } & Agree & $8(11.4)$ & $28(9.8)$ & \multirow{2}{*}{0.067} \\
\hline & & Disagree & $62(88.6)$ & $259(90.2)$ & \\
\hline \multirow[t]{2}{*}{6} & \multirow[t]{2}{*}{ I think that I cannot help having false teeth when I am old } & Agree & $37(52.9)$ & $158(55.1)$ & \multirow{2}{*}{0.087} \\
\hline & & Disagree & $33(47.1)$ & $129(44.9)$ & \\
\hline \multirow[t]{3}{*}{7} & \multirow[t]{3}{*}{ I am bothered by the color of my gums } & Agree & $37(52.9)$ & $151(52.6)$ & \multirow{3}{*}{0.486} \\
\hline & & Disagree & $33(47.1)$ & $136(47.4)$ & \\
\hline & & Total & 70 & 287 & \\
\hline \multirow[t]{2}{*}{8} & \multirow[t]{2}{*}{ I think my teeth are getting worse despite my daily brushings } & Agree & $22(31.4)$ & $127(44.3)$ & \multirow{2}{*}{0.041} \\
\hline & & Disagree & $48(68.6)$ & $160(55.7)$ & \\
\hline \multirow[t]{2}{*}{9} & I brush each of my teeth carefully & Agree & $41(58.6)$ & $229(79.8)$ & 0013 \\
\hline & & Disagree & $29(41.4)$ & $58(20.2)$ & 0.013 \\
\hline 10 & I have never been taught professionally how to brush & Agree & $24(34.3)$ & $92(32.1)$ & (14014 \\
\hline & & Disagree & $46(65.7)$ & $195(67.9)$ & 0.014 \\
\hline 11 & I think I can clean my teeth well without using a toothbrush & Agree & $12(17.1)$ & $56(19.5)$ & 0058 \\
\hline & & Disagree & $58(82.9)$ & $231(80.5)$ & 0.050 \\
\hline 12 & I often check my teeth in the mirror after brushing & Agree & $43(61.4)$ & $248(86.4)$ & 184 \\
\hline & & Disagree & $27(38.6)$ & $39(13.6)$ & 0.184 \\
\hline 13 & I worry about having bad breath & Agree & $51(72.9)$ & $236(82.2)$ & 0654 \\
\hline & & Disagree & $19(27.1)$ & $51(17.8)$ & 0.034 \\
\hline 14 & It is impossible to prevent gum diseases with toothbrushing alone & Agree & $43(62.9)$ & $198(69)$ & 4ح0 \\
\hline & & Disagree & $27(37.1)$ & $89(31)$ & \\
\hline 15 & I put off going to the dentist until I have a toothache & Agree & $44(62.9)$ & $116(40.4)$ & 0138 \\
\hline & & Disagree & $26(37.1)$ & $171(59.6)$ & 0.138 \\
\hline 16 & I have used a dye to see how clean my teeth are & Agree & $18(25.7)$ & $36(12.5)$ & 0034 \\
\hline & & Disagree & $52(74.3)$ & $251(87.5)$ & 0.034 \\
\hline 17 & I use a toothbrush which has hard bristles & Agree & $26(37.1)$ & $43(15)$ & 0078 \\
\hline & & Disagree & $44(62.9)$ & $244(85)$ & 0.078 \\
\hline 18 & I do not feel I have brushed well unless I brush with strong strokes & Agree & $22(31.4)$ & $81(28.2)$ & 0654 \\
\hline & & Disagree & $48(68.6)$ & $206(71.8)$ & 0.054 \\
\hline 19 & I feel I sometimes take too much time to brush my teeth & Agree & $39(55.7)$ & $142(49.5)$ & 238 \\
\hline & & Disagree & $31(44.3)$ & $145(50.5)$ & 0.238 \\
\hline 20 & I have had my dentist tell me that I brush very well & Agree & $25(35.7)$ & $121(42.2)$ & 0.068 \\
\hline & & Disagree & $45(64.3)$ & $166(57.8)$ & 0.000 \\
\hline
\end{tabular}

Kawamura et al. showed that with increasing age and exposure to the dental field the oral health attitude and behavior change among Japanese dental students. ${ }^{8}$ Overall, in our study, clinical students had better dental health awareness than preclinical students. However, these differences may be because of their training and clinical exposure and experience.

In our study, there was a significant relationship between participants' gender and their HU-DBI scores. Overall, female participants were found to have better knowledge and attitude toward their oral care and willingness to consult a dental surgeon as a precaution. These results are in agreement with the results of previous studies. ${ }^{19,20}$ Sujatha et al. reported that female dental students had a better oral health attitude and took better care of their teeth than their male counterparts. ${ }^{21}$ According to previous studies, females have a better attitude toward the maintenance of oral hygiene and take better care of their oral health than males. ${ }^{22,23}$ The positive attitudes and behaviors of females toward oral health care can be explained from a psychological point of view. In general, 
females are usually concerned and take more care about their body's healthiness and appearance. ${ }^{24}$ They are also more concerned about their oral health care and visiting the dentist; they are more likely to have oral healthcare knowledge even before entering dentistry. ${ }^{11,24}$ Overall, the oral healthcare knowledge among the participants of this study was good, although they had inadequate knowledge in a few areas, such as the effective brushing force, proper brushing methods, and the use of disclosing agents to identify deposits on the teeth. This study shows that oral care knowledge and practice improve among dental students with increasing levels of education and training. This study provides some valuable insight into the level of oral healthcare knowledge among dental students and allows its comparison with various levels of the curriculum.

To induce a change in the society, it is important to change the thoughts and the social environment of the society, which in turn changes the ability to understand a situation and execute decisions in individuals. ${ }^{25}$ Any misconception about programs will have a negative impact on a person. To change or prevent misconceptions, we should educate common people and properly explain programs to them, which will yield positive results. Therefore, the educators should be trained properly to clarify people's doubts and should become their role models; dental students should play this role in raising community's dental health awareness. ${ }^{18}$ Even though our study showed a correlation among knowledge, attitude, gender, and educational level, it had a small sample size; hence, its results cannot be generalized to other dental colleges. A further study involving multiple dental colleges from different regions might reveal stronger relationships among knowledge, attitude, gender, and educational level than those reported previously.

This study shows that students' oral hygiene knowledge and practice increase with their level of education. Therefore, we conclude that the introduction of basic oral health awareness-related topics in the preuniversity curriculum might be beneficial to society.

\section{Acknowledgments}

The authors are grateful to all the subjects who participated voluntarily and cooperated for the success of this study.

Criteria for inclusion in the authors: They have contributed in this study design, analyzing data, and writing article.

\section{References}

1. Babu A, Santosh R, Muddana K. Viral infections of oral cavity. J Family Med Prim Care 2020;9(1):36-42. DOI: 10.4103/jfmpc. jfmpc_807_19.

2. Nazir MA. Prevalence of periodontal disease, its association with systemic diseases and prevention. Int J Health Sci 2017;11(2):72-80 .

3. Jin L, Lamster IB, Greenspan JS, et al. Global burden of oral diseases: emerging concepts, management and interplay with systemic health. Oral Dis 2016;22(7):609-619. DOI: 10.1111/odi.12428.

4. Puy CL. The role of saliva in maintaining oral health and as an aid to diagnosis. Med Oral Patol Oral Cir Bucal 2006;11(5):E449-E455.

5. Petrauskiene S, Mushayev H, Zemgulyte G, et al. Oral Health Awareness among International Dental and Medical Students at Lithuanian University of Health Sciences: a cross-sectional study. J Oral Maxillofac Res 2019;10(4):e31-e39. DOI: 10.5037/ jomr.2019.10403.

6. Rabiei S, Mohebbi SZ, Patja K, et al. Physicians' knowledge of and adherence to improving oral health. BMC Public Health 2012;12:855. DOI: $10.1186 / 1471-2458-12-855$.
7. Baiju RM, Peter E, Varghese NO, et al. Oral health and quality of life: current concepts.J Jlin Diagn Res 2017;11(6):ZE21-ZZE6. DOI: 10.7860/ JCDR/2017/25866.10110.

8. Kawamura M, Kawabata K, Sasahara H, et al. Dental behavioral science: Part IX. Bilinguals' responses to the dental behavioral inventory (HUDBI) written in English and in Japanese [in Japanese]. J Hiroshima Univ. Dent. Soc. 1992;22:198-204. DOI: 10.1111/j.1875-595X.2002.tb00621.x.

9. Nirmala SG, Quadhar MA, Veluru S, et al. Oral health behaviour among medical, dental and paramedical students - a cross sectional study. Carib J Sci Tech 2015;3:774-780.

10. Glick M, Williams DM, Kleinman DV, et al. A new definition for oral health developed by the FDI world dental federation opens the door to a universal definition of oral health. J Public Health Dent 2017;77:3-5. DOI: 1016/j.ajodo.2016.11.010. PMID: 28153139.

11. Baseer MA, Rahman G, Al Kawaey Z, et al. Evaluation of oral health behavior of female dental hygiene students and interns of Saudi Arabia by using Hiroshima University dental Behavioural inventory (HU-DBI). Oral Health Dent Manage 2013;12(4):255-261.

12. Okoh $\mathrm{H}$, Enabulele J. Influence of clinical experience on oral health attitude and behaviour of dental students attending a Nigerian university. Odontostomatol Trop 2014;37(148):25-31.

13. Vangipuram S, Rekha R, Radha G, et al. Assessment of oral health attitudes and behavior among undergraduate dental students using Hiroshima University Dental Behavioral Inventory HU-DBI. J Indian Assoc Public Health Dent 2015:13(1);52-57. DOI: 10.4103/23195932.153587.

14. Moheet IA, Farooq I. Self-reported differences between oral health attitudes of pre-clinical and clinical students at a dental teaching institute in Saudi Arabia. Saudi Dent J 2013;25(4):149-152. DOI: 10.1016/j.sdentj.2013.07.001.

15. Okoh M, Enabulele J. Gender differences in oral health attitudes and behaviour among Nigerian clinical dental students. Niger Dent J 2013;21(1):27-31.

16. Saran R, Kumar S. Oral health knowledge, attitude and behaviour of medical and dental students. Int J Sci Res 2016;5:59-60. DOI: 10.4103/ jispcd.JISPCD_30_17.

17. Zetu I, Zetu L, Dogaru CB, et al. Gender variations in the psychological factors as defined by the theory of planned of oral hygiene behaviors. Procedia Soc Behav Sci 2014;127:353-357. DOI: 10.1016/j. sbspro.2014.03.270.

18. Ozyemisci-Cebeci N, Unver S, Nemli SK. A comparative study of oral health attitudes and behaviours in dental students. J Dent Appl 2014;1(1):3-7. DOI: 10.2334/josnusd.55.23.

19. Almarek F, Assery MK, Baseer MA. Oral health attitudes and behavior among health professionals in Riyadh City, Saudi Arabia. J Int Oral Health 2017;9(4):157-164. DOI: 10.4103/jioh.jioh_134_17.

20. Ahamed S, Moyin S, Punathil S, et al. Evaluation of the oral health knowledge, attitude and behavior of the preclinical and clinical dental students. J Int Oral Health 2015;7(6):65-70.

21. Sujatha B, Yavagal PC, Nagesh L, et al. A study of oral health awareness among undergraduate medical students in Davangere City - a cross sectional survey. Indian J Public Health Res Develop 2015;6:243. DOI: 10.4103/2319-5932.138958.

22. Yao K, Yao Y, Shen X, et al. Assessment of the oral health behavior, knowledge and status among dental and medical undergraduate students: a cross sectional study. BMC Oral Health 2019;19(1):26. DOI: 10.1186/s12903-019-0716-6.

23. Kumar H, Behura SS, Ramachandra S, et al. Oral health knowledge, attitude, and practices among dental and medical students in Eastern India - a comparative study. J Int Soc Prev Community Dent 2017;7(1):58-63. DOI: 10.4103/jispcd.JISPCD_30_17.

24. Puri MS, Puri N, Singh K, et al. Influence of dental education on oral health attitude and behavior of 1st year dental students through Interns. EC Dent Sci 2015;1(2):225-231. DOI: 10.1038/s41405-019-0024-x.

25. Al-wesabi AA, Abdelgawad F, Sasahara $H$, et al. Oral health knowledge, attitude and behaviour of dental students in a private university. BDJ Open 2019;5:16. DOI: 10.1038/s41405-019-0024-x. 